\title{
The estimation of carbon emission on the result of road transportation reallocation
}

\author{
Vikri Januarisma ${ }^{1 *}$, and Iwa Garniwa ${ }^{1}$ \\ ${ }^{1}$ Electrical Engineering Department, Engineering Faculty, Universitas Indonesia, Jakarta, 10430, \\ Indonesia.
}

\begin{abstract}
Carbon emission reduction becomes a concern in the development of road transportation. Government policy and direction perform a vital role in the current condition. This study aims to estimate the total carbon emission influenced by several conditions: vehicle volume, vehicle speed, public transportation involvement, and implementation of odd-even vehicle plate policy using system dynamics modeling. According to the result, it is shown that the involvement of public transportation and the effectiveness of odd-even plate implementation has been decreased sharply in 2030 to $2,79 \mathrm{E}+05$ tons $\mathrm{CO} 2 \mathrm{e}$ from $7,00 \mathrm{E}+11$ ton CO2e. That condition is applied for the same assumption of $40 \%$ the effectiveness oddeven plate implementation, fuel economy ratio $16 \mathrm{~km} / \mathrm{l}$, total travel distance $214 \mathrm{~km}$, and speed vehicle $70 \mathrm{~km} / \mathrm{h}$. Therefore, the Government's role in improving, providing, or adding public transportation frequency is highly recommended in future development.
\end{abstract}

\section{Introduction}

The greenhouse gas (GHG) effect plays a significant role in climate change. One of the concerns is that the increment of transportation gas emissions is becoming a global issue [1]. Carbon dioxide particularly being targeted to be substantial emission reduction in a metropolitan city such as Greater Jakarta. According to the Provincial Government of DKI Jakarta, GHG emission reduction is being forced to reach up to maximum 35 million tonnes of $\mathrm{CO} 2 \mathrm{e}$ in 2030, with current data presented that the transportation, commercial, and household are listed as second highest that contributed GHG emission up to $33.48 \%$ or equal to $19,269,210$ ton $\mathrm{CO} 2 \mathrm{e}$ in 2018 after the electricity consumption on the point of $48,93 \%$ [2]. In addition to that condition, the Government offered several solutions in providing various public transportation such as Commuter line (KRL), Mass Rapid Transit (MRT), Light Rail Transit (LRT), Bus Rapid Transit (BRT), and other public transportations that have been implemented in order to occupy public mobility from one point to another point nearby Jakarta area. The objective of this study aims to estimate the total carbon emission emitted by public and private transportations in Jakarta using system dynamics modeling by considering their vehicle volume, public transportation ratio, oddeven policy effectiveness, and vehicle speed assumption. Therefore, it helps to determine

\footnotetext{
* Corresponding author: vikri.januarisma@ui.ac.id
} 
the difference between each variable and their ratio to meet the maximum value GHG reduction in 2030.

Globally, road transportation implementation in developed and developing countries have similarity in term of road transportation type regardless of integrated technological implementation issues on public transportation and private car. They offered BRT, MRT, LRT, and KRL as their main public transportation. All those types of road transportationrelated with its fuel, therefore its energy consumption reduction, have been linked to public transportation support variances to substitute private cars [3]. Besides, the increment of private car ownership is related to traffic conditions that caused the speed variation in a different hour [4]. In Jakarta, BRT is implemented after KRL that provides an articulated bus, single bus, and maxi bus to cover the Jakarta area's inner city with a special line. It differs with KRL that covers intercity between Jakarta - Bogor - Depok - Tangerang Bekasi - Cikarang - Banten areas with a total length of $418.5 \mathrm{~km}$. Compare to BRT and KRL, both MRT and LRT have less travel distance in kilometer. The first phase MRT is operated in 2019 about 16 kilometers from Lebak Bulus station to Bundaran Hotel Indonesia station [5], and LRT remains an in-progress project [6]. However, besides all the differences, BRT, KRL, MRT, and LRT are considered as massive progress from the Government to substitute and support GHG emission reduction and traffic congestion in the Jakarta area.

The number of vehicle volume increases up to $75 \%$ in Jakarta from 12 million to 21 million from 2016 to 2019 [7] reinforced the Government to be innovative to offer various public transportation. Although each of the solutions like BRT Jakarta encountered some difficulties in terms of several aspects [8], the Government fixed them in the upcoming year ahead and took an aggressive movement to operate the first MRT phase in 2019. The summary of public transportation available in DKI Jakarta is listed in table 1. The government's milestones are likely expanding the coverage of BRT, MRT, and KRL for future development, with the confirmation of the LRT project in the upcoming year 2021. Lastly, expand the coverage point for the implementation of the odd-even policy. Odd-even is implemented by the DKI Jakarta government starting in August 2016. Odd-even plate implementation aims to help reduce GHG emission [9] and alternate the vehicle usage inherent to the traffic reduction. However, other studies discovered that odd-even plate implementation ineffective in reducing GHG emissions due to shifting driving time behavior [10].

Table 1. Lists of public transportation availability in Jakarta area.

\begin{tabular}{|c|c|c|c|c|c|}
\hline No & Types & $\begin{array}{c}\text { No. of Unit } \\
\text { Operation }\end{array}$ & $\begin{array}{c}\text { Total routes/ } \\
\text { stations }\end{array}$ & $\begin{array}{c}\text { Total } \\
\text { customer }\end{array}$ & References \\
\hline 1. & BRT & 870 units & 55 routes & $\begin{array}{c}152 \text { million } \\
\text { annually }\end{array}$ & {$[11]$} \\
\hline 2. & MRT & N/A & 13 stations & 89,000 daily & {$[5]$} \\
\hline 3. & KRL & 1,100 units & 10 routes & 979,853 daily & {$[12]$} \\
\hline
\end{tabular}

Therefore, to examine the total performance of public transportation response and oddevent implementation effectiveness towards the amount of total carbon dioxide emission produces, this study initiates to develop the model using system dynamics modeling with aims to address various dependent and independent variables in a system with value changes over a certain period [13]. 


\section{Method}

This study covers five major tolls in the Jakarta area, including Jagorawi, JakartaCikampek, Jakarta-Tangerang, Camareng, and Lingkar Luar, a total distance of 214 kilometers. The vehicle volume is taken according to the total number of vehicle travel passing each gateway in 2019. This study has limitations in excluding the total registered vehicle in Jakarta and other types of roads; therefore, it is beneficial for further study improvement.

This study aims to identify the factor that caused the carbon emission problem on road transportation and uses system dynamic modelling (Vensim software 8.1.0 version) to perform the causal loop diagram (CLD), as shown in figure 1. It emphasizes the relationship factor such as fuel economy, public transportation ratio, odd-even policy effectiveness, and vehicle speed that subsequently influence the system, subsequently running and simulating the given equation in each variable. At the beginning of the process, dependent and independent variables are set up inherently to the factor that leads to road transportation [14].

All those variables will be executed in the simulation, where the result helps to find the estimation of total carbon emission. It will persuade the Government to track the current condition towards the target in 2030. Therefore, if the analysis has shown the result greater than the Government's expected target, the necessary improvement shall be taken, else the emission reduction target remains. Not only mentioning the achievement target of Government but also it aims to reduce GHG emission [15] in overall.

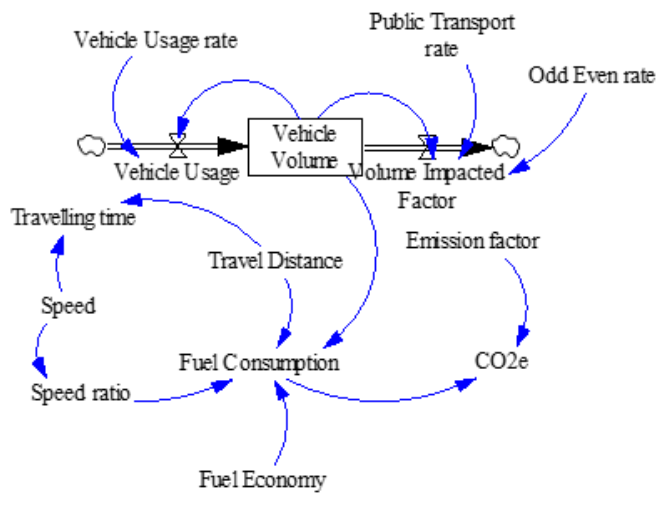

Fig. 1. Causal loop diagram.

The analysis of total emission in road transportation deploys by several variables that interact to the activity movement [16]. It produces carbon dioxide as their main emission [17], and further known as global particle reductions against GHG emission. The general formula for this study is shown below:

$$
\mathrm{CO} 2_{\mathrm{a}, \mathrm{b}}=\mathrm{FC}_{\mathrm{a}, \mathrm{b}} * \mathrm{EF}^{*} 10^{-6}
$$

where,

$\mathrm{CO} 2 \mathrm{a}, \mathrm{b}$ is the total amount of carbon emission in tones unit that influenced by the length of travel distance from origin ' $a$ ' to destination ' $b$,' fuel economy of the vehicle, vehicle volume that travels from origin ' $a$ ' to destination ' $b$,' speed ratio from origin ' $a$ ' to destination ' $b$,' and emission factor.

EF is the characteristic of pollutant release to the atmosphere per litter for each type of vehicle. The setting values are 3,172 and 3,180 [18]. and, 


$$
F C_{\mathrm{a}, \mathrm{b}}=\left(T D_{\mathrm{a}, \mathrm{b}} / \mathrm{FE}\right) * V e v_{\mathrm{a}, \mathrm{b}} * \mathrm{SR}
$$

where,

$\mathrm{FC}$ is the fuel consumption in a litter for each vehicle that travels from origin ' $\mathrm{a}$ ' to destination ' $b$.'

TD is the length of distance from origin ' $a$ ' to destination ' $b$ ' in kilometer. The setting values from 2 to 214 [19].

FE is the added value of the economy for each type of vehicle in kilometer per litter. The setting values between 3.5 to 16 [18].

$\mathrm{SR}$ is the comparison between speed constant to speed variation from origin ' $\mathrm{a}$ ' to destination ' $b$ ' with assumption of speed constant $70 \mathrm{~km} / \mathrm{h}$ [20] and speed variation at traffic condition $20 \mathrm{~km} / \mathrm{h}$ [21]. and,

$$
V e v_{\mathrm{a}, \mathrm{b}}=\left[\mathrm{UV}_{\mathrm{a}, \mathrm{b}}-\left(\mathrm{PT}_{\mathrm{a}, \mathrm{b}}+\mathrm{OE}_{\mathrm{a}, \mathrm{b}}\right)\right]
$$

where,

Veva,b, is the annual cumulative of vehicle volume. The setting value is $8,20659 \mathrm{E}+08$ [7].

UVa,b is the amount of vehicle usage rate. The setting value is $100 \%$.

$\mathrm{OEa}, \mathrm{b}$ is the amount of odd-even policy effectiveness rate that affected to the vehicle volume. The setting values are made by assumption effectiveness 0 and $40 \%$ [22].

$\mathrm{PTa}, \mathrm{b}$ is the amount of public transportation rate that affected the vehicle volume. The setting values are made by assumption effectiveness 0 and $15 \%$ [23].

\section{Results and discussion}

Studies in the past shown that the development of public transportation [24], energy efficiency acceleration through fuel economical vehicle [25], and traffic condition [26] are part of carbon emission reduction application and odd-even effectiveness to reduce air pollution [27] are essential to GHG movement [28]. According to the result in figure 2, it is inline that the resulting output between the x-axis and $y$-axis has a positive impact on carbon emission reduction with several probabilities to estimate the total carbon emission with changing of public transport ratio odd-even ratio, fuel economy, and speed. It is shown that probability $5-8$ created the best combination to perform carbon emission reduction between $2,79 \mathrm{E}+05$ ton $\mathrm{CO} 2 \mathrm{e}$ to $1,74 \mathrm{E}+09$ ton $\mathrm{CO} 2 \mathrm{e}$ compared with probability $1-4$ that varies between $2,45 \mathrm{E}+11$ ton $\mathrm{CO} 2 \mathrm{e}$ to $4,35 \mathrm{E}+12$ ton $\mathrm{CO} 2 \mathrm{e}$. These happened because several factors have a major influence on carbon emission reduction with further explanation through the following subsection. 


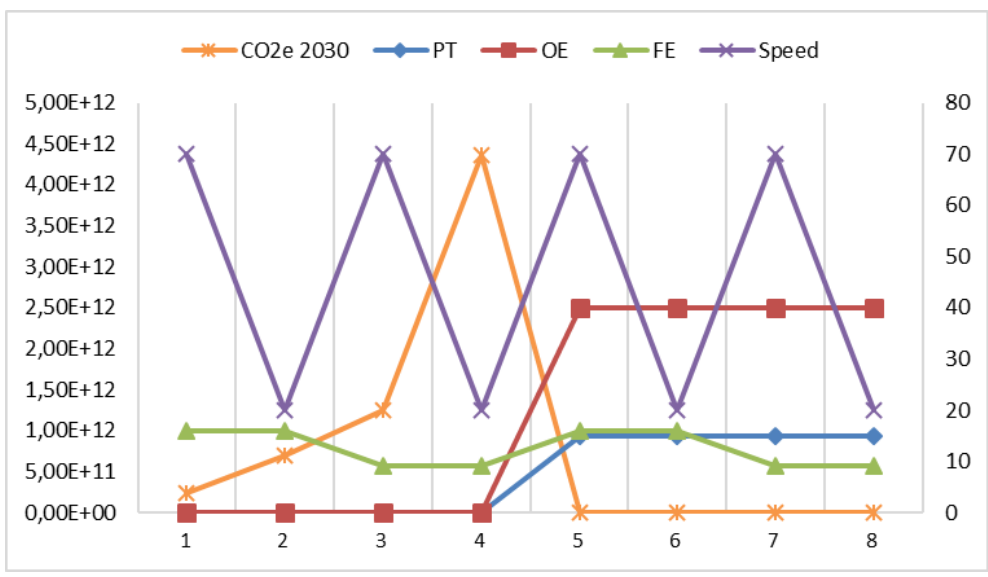

Fig. 2. Probability matric of carbon emission estimation in 2030 .

\subsection{Public transportation}

This study set the initial value of 0 to 15 percent of public transportation usage effectiveness by reducing private vehicle density volume, showing a major effect on carbon emission reduction. It is shown that higher involvement possibilities tend to reduce carbon emission gradually. Besides, it reduces carbon emissions, and indirectly it has a social impact on controlling car ownership [29] and considers public tendency to move from private vehicles to a mass transit system. Aside from the previous view, controlling public transportation and other vehicles with energy efficiency or eco-friendly environment technology could significantly reduce carbon emissions.

\subsection{Odd-Even policy}

Another solution provided is the implementation of an odd-even policy. This solution is applicable only in certain areas with a higher carbon emission concentration, reducing an individual vehicle travel movement. It is relevant to Metropolitan cities such as Jakarta, which has a high-density level in industries, offices, and residential. Therefore, the tendency for human mobilization, especially in the transportation sector, will likely higher than any other area. This study set the effectiveness rate between 0 to 40 percent, showing the same result from the previous solution; the higher successful implementation rate will result in the lowest carbon emission. However, this is inversely proportional to another study that mentioned that an odd-even policy is applicable for the short term period only [30] because it motivates the drivers to look for alternative routes to avoid its implementation. In addition, it is also shifting the habit of driving at certain hours.

\subsection{Fuel economy}

Fuel economy is part of technological advances. Europe has set the emission threshold for new and old vehicle generation using the Euro emission standard. Therefore, many vehicles have implemented eco-friendly environmental engine technology [31]. As a capital city of Indonesia, Jakarta adopted carbon emission test for diesel and gasoline fuel type of vehicle starting 2019 [32]. It does not only help to reduce the GHG emission but also controlling the effect of fuel consumption. 


\subsection{Speed}

As one of high populated vehicle ownership, Jakarta has affected traffic congestion in a certain area and during peak hours. As the traffic became congested, speed variation occurs. The lower the vehicle's speed, the longer it stays in an area and increases fuel consumption. Thus, it will affect a higher ratio of carbon emission. This study set the value of normal conditions at 70 kilometers per hour [20] and 20 kilometers per hour [21] at traffic conditions to calculate the impact on the total amount of carbon emission reduction.

\section{Conclusion}

According to the solution provided in this study, the Government is encouraged to expand the frequency and improve the diversity of public transportation; hence it possible to enforce private vehicle usage and to reduce the traffic congestion. In addition, the commitment between the Government and the industrial automotive sector to support ecofriendly environment vehicles is highly recommended to improve engine efficiency. Therefore, energy-saving, fuel economy, and carbon emission tests are being subjective control items for further improvement.

\section{Acknowledgements}

This study is funded by DRPM (Directorate of Research and Community Service) the Universitas Indonesia.

\section{References}

1. N. Shurpali, A.K. Agarwal, V.K. Srivastava, Introduction to greenhouse gas emissions (Springer, Singapore, 2019) https://link.springer.com/chapter/10.1007/978-981-133272-2 1

2. Pemerintah Provinsi DKI Jakarta (2018) (Indonesian language)

3. C.N. Businge, S. Viani, N. Pepe, M. Borgarello, C. Caruso, G. Tripodi, S. Soresinetti, Energy efficiency solution for sustainable urban mobility: case study of the Milan metropolitan area, WIT transaction on the built environment, Urban transport XXIV, 182, 151-163 (2019) https://doi.org/10.2495/UT180151

4. A.M. Karim, D. Priharyaningsih, L. Veronika, Proyeksi kecepatan kendaraan dan emisi CO2 di DKI Jakarta tahun 2015 - 2030 dengan pendekatan system dynamics, Jakarta (2018) (Indonesian language) http://ejournal.uika-bogor.ac.id/index.php/komposit/article/view/1546

5. MRT Jakarta (2019) (Indonesian language)

6. LRT Jakarta (2020) (Indonesian language)

7. Badan Pusat Statistika (BPS) Jakarta (2019) (Indonesian language)

8. S. Angelina, D. Vallee, C. Louen, The barriers in the implementation process and the operation of innovative urban transport: the case of BRT Jakarta, in WIT transaction on the built environment, Urban transport XXIII, 176, 69-80, Germany (2017) https://doi.org/10.2495/UT170071

9. R.K. Mishra, A. Pandet, G. Pandey, A. Kumar, The effect of odd-even driving scheme on PM2.5 and PM1.0 emission, in Elsevier: Transportation research Part D: transportation and environment, 67, 541-552 (2019) https://doi.org/10.1016/i.trd.2019.01.005 
10. B.P. Chandra, V. Sinha, H. Hakkim, A. Kumar, H. Pawar, A.K. Mishra, G. Sharma, Pallavi, S. Garg, S. D. Ghude, D. M. Chate, P. Pithani, R. Kulkarni, R.K. Jenamani, M. Rajeevan, Odd-even traffic rule implementation during winter 2016 in Delhi did not reduce traffic emission of VOCs, carbon dioxide, methane and carbon monoxide, in Current Science, 114, 6, 1318-1325. 8p (2016) https://www.currentscience.ac.in/Volumes/114/06/1318.pdf

11. Pejabat Pengelola Informasi dan Dokumentasi (PPID) Transjakarta (2019) (Indonesian language)

12. PT. Kereta Commuter Indonesia (KRL), (2019) (Indonesian language)

13. V. Ghisolfi, G.M. Ribeiro, G.D.L.D. Chaves, R.D.O. Filho, I.C.S. Hoffmann and L.R. Perim, Evaluating impact of overweight in road freight transportation: a case study in Brazil with system dynamic, in MDPI: Sustainability, 11, 11 (2019) https://doi.org/10.3390/su11113128

14. L. Zhang, L. Liu, M. Wang, Y. Wang, Y. Zhou, Forecast and analysis of road transportation energy demand under the background of system dynamics, in IOP Conference Series: Earth and Environmental Science, 252, 5 (2019) https://doi.org/10.1088/1755-1315/252/5/052043

15. I.C. Setiawan, Indarto, Deendarlianto, System dynamics modelling of Indonesia Road Transportation Energy Demand and Scenario Analysis to achieve National Energy Policy Target, in IOP Conference Series: Material Science and Engineering, 546, 5 (2019) https://doi.org/10.1088/1757-899X/546/5/052070

16. D. Muziansyah, R. Sulistyorini, S. Sebayang, Model emisi gas buangan kendaraan bermotor akibat aktivitas transportasi (studi kasus: terminal pasar bawah Ramayana koita bandar lampung), in Jurnal Rekayasa Sipil dan Desain, JRSDD, 3, 1, 57-70 (2015) (Indonesian language) https://journal.eng.unila.ac.id/index.php/jrsdd/article/view/394

17. L. Yang, Y. Wang, S. Han, Y. Liu, Urban transport carbon dioxide (CO2) emissions by commuters in rapidly developing Cities: The comparative study of Beijing and $\mathrm{Xi}$ ' an in China, in Transportation Research Part D: Transport and Environment, 68, 65-83 (2019) https://doi.org/10.1016/j.trd.2017.04.026

18. G. M. Hatta, Peraturan menteri negara ningkungan hidup nomor 12 tahun 2010 tentang pelaksanaan pengendalian pencemaran udara di daerah (Jakarta, 2010) (Indonesian language)

19. B. Airlangga, Provinsi DKI Jakarta dalam angka 2020 (Badan Pusat Statistika, Jakarta, 2020) (Indonesian language)

20. K. McDonough, I. Kolmanovsky, D. Filev, D. Yanakiev, S. Szwabowski, J. Michelini, Stochastic dynamic programming control policies for fuel efficient vehicle following, in American Control Conference (ACC), USA (2013) https://doi.org/10.1109/ACC.2013.6580024

21. Jasa Marga Jakarta, (2019) (Indonesian language)

22. H. Shahbazi, V. Hosseini, M. Hamedi, Investigating the effect of odd-even day traffic restriction policy on Tehran air quality, in conference of transportation research board 93rd annual meeting, USA (2014) https://trid.trb.org/view/1289278

23. Z. Didili, (2019)

24. W. S. Ng, Urban transportation mode choice and carbon emission in Southeast Asia, in Transportation research record, 2672, 2, 54-67 (2018) https://doi.org/10.1177/0361198118797213

25. T. O. Akinyemi, O. J. Ramonu, Mitigation of CO2 Emissions in Transportation and Industrial Processes Using Renewable Energy Technologies, in European Journal of Engineering Research and Science, 4, 5, 58-66 (2019)

https://doi.org/10.24018/ejers.2019.4.5.1118 
26. Y. Dong, J. Xu, X. Liu, C. Gao, H. Ru, Z. Duan, Carbon Emissions and Expressway Traffic Flow Patterns in China, in Sustainability, 11, 10 (2019) https://doi.org/10.3390/su11102824

27. K. Singhania, G. P. Girish, E. N. Vincent, Impact of odd-even rationing of vehicular movement in Delhi on air pollution level, 7, 151-160 (2016) https://doi.org/10.4236/lce.2016.74014

28. Y. Ismail, A. D. Nurwidyawati, A. D. Rahayu, Estimation of vehicle carbon dioxide (CO2) emission, in Journal of Industrial Engineering, Scientific Journal on Research and Application of Industrial System, 4, 2, 94-99 (2019) http://dx.doi.org/10.33021/jie.v4i2.894

29. H. Min, Assessing the efficiency of mass transit system in the United States, in Mineta transportation institute publications, USA (2017)

http://transweb.sjsu.edu/PDFs/research/1235-assessing-the-efficiency-of-mass-transitsystems-in-the-united-states.pdf

30. M. Farda, C. Balijepalli, Exploring the effectiveness of demand management policy in reducing traffic congestion and environmental pollution: car-free day and odd-even plate measures for Bandung city in Indonesia, in World conference on transport research society, 6, 577-590 (2018) https://doi.org/10.1016/j.cstp.2018.07.008

31. P. Bielaczyc, A. Szczotka, J Woodburn, Carbon dioxide emissions and fuel consumption from passenger cars tested over the NEDC and WLTC - an overview and experimental results from market-representative vehicles, in IOP Conference Series: Earth and Environment Science, 214 (2019) https://doi.org/10.1088/1755$\underline{1315 / 214 / 1 / 012136}$

32. Pemerintah Provinsi DKI Jakarta (2019) 